\title{
The Role of Sport Programs in Peace Building. Anthropological Study at El-Zhour Club in Cairo
}

\author{
Dr. Samah Ahmed Faried Mostafa \\ Associate Professor at Philosophy and sociology Dep., \\ Faculty of Education, Ain shams University, Egypt
}

Doi:10.19044/esj.2018.v14n29p244 URL:http://dx.doi.org/10.19044/esj.2018.v14n29p244

\begin{abstract}
In Egypt, after leading change in the 2011 revolution, and being the majority of the Egyptian population, young Egyptians became the focus of much attention in the political and media speech. Sport for peace building has become an acknowledged policy in underprivileged communities both in the developing and developed world. The study argues that sport for peace programs in Egypt hold the potential role not only to alter structural violence but also to prevent the violence in the form of extremism. This study aims to place the perception of the sport importance and its influence' on youth manner especially towards peace building and conflict resolution. It is important to reveal youth' perception and their recommendations about peace and conflict after participating in some sports program at the club. The purpose of this paper is to determine the current barriers faced by Egyptian sport federations in their policy to reduce the social conflict.

The data set is made up of youth and expert interviews, coaches and supplemented by ethnographic records about youth sport programs collected by the author through observation and scale. The methodology of the study is based on both the descriptive analytical method and a Likert Scale measurement. The results discovered the need of extra definitions and applications from the religious, art and cultural program beside the sports program to achieve the peace building. They suggested extra programs which may develop their character such as the development of cultural and social awareness.
\end{abstract}

Keywords : Sport Program, Peace Building, Youth

\section{Introduction}

In different regions affected by poverty and conflict, sport has recently been approved by the international community as a tool for economic development and as a catalyst for social inclusion, reconciliation, tolerance and 
peace building. As a matter of fact, Peace building is treated as learned behaviour because its cross-cultural nature, sport has unique way to break through barriers of all kind and therefore can be a major factor of any social intervention.

Youth empowerment and participation in shaping the future of their country became one of the primary concerns after the Egyptian revolution especially in the current regime. Many of Egyptian leaders and experts still trying to find out the ways to integrate more youth inside their society and became part of the solution of the conflict events which be happened recently in different situations. The research purpose is to identify the extent to which youth aspirations, perceptions, anticipations and dreams are incorporated in the process of sport programs.

Egypt transition to be peaceful society has brought great progress to many of its people and aspects, However, many tensions and inequalities are still present in the real life. Youth still are struggling to have some benefits from this transmission. There are no "quick fix" solutions to youth problems. However, the sport can facilitate the process and thus contribute to the community development and peace building. Today, there is difficulty to participation access in sport activities especially for poor people, for that reason the study trying to highlight the power of sport in preventing the conflict and improving peace manner.

\section{The Importance of the study:}

1. The theoretical importance of this study is trying to do some subjects in the sociology of peace field due to limited research and studies that have been the subject field of study, where it in spite of the growing .

2.The growing importance of sports to the national security of Egypt.

3. The importance of access to research findings shed light on Sport that may help decision-makers in the development of this type of peace building.

\section{Aims and Hypotheses}

This research tries to analyse the following aims:

1- Analyses the youth perception towards the importance of sports in their life.

2- Evaluate and analysis of Sports, Social and cultural program in Egyptian clubs as one of the ways to peace building.

3- Studying and analyzing of impediments to sports programs in Egypt.

4- discover the circumstances under which sport can or might work toward peace.

5- Address issues of identity, belonging, and cultural isolation amongst youth who participated in the sport programs. 
According to those aims, there are two hypnosis were highlighted at this study :

- There is a relationship between feeling peace and participating in some sports program.

- There is relationship between the level of Peace and being member at social and cultural programs

\section{Methodology}

The methodology of the study is based on both the descriptive analytical method and a Likert Scale measurement. The research conducted a qualitative analysis of empirical field research based on interviewing approach for sport practitioners,.

Also the current research depends on Anthropological method and case study method which the club is considered the analyses unit, Also the research method depends on the Anthropological field guide which sets to cover all the items starting from the club history, its structure, its programs and all kinds of the social and culture programs among youth there. Also the research applied an interview guide with some youth who have some experience with different social and sport programs and with some experts who are participating in conducting those programs and have more 10 years' experience in planning sport programs at the club.

The questionnaire asked about the probability of some programs happening in each of the environments described above and the respondent's judgment as to the impact of the proposed challenge.

The study relied on a random sample of Representatives from the club, A total of 110 persons completed the scale. All interviewed participants were over eighteen years of age .

\section{Theoretical Framework}

This research depends on some functional theory works and Symbolic Internationalism Theory works. Sport is studied in terms of its contribution to the system and how it helps keep societies, communities, groups and organizations operating smoothly, as well as how it influences individuals to contribute to the social systems in which they participate. Sport is seen as a source of inspiration for individuals and society, so using the functional theory to make decisions about sport to promote social integration through development and growth in organized youth sport. Sport participation and individual development can fight nonconformity through elite programmers, build values and expose children to sporting role models (sociology of sports:2018).

On the other hand, the mark of peace studies is apparent in international, regional, and interpersonal discourses and may also be referred 
to as the study of conflict resolution or conflict transformation (Lederach, 2003). As a field of specialization, peace studies has benefited from scholarly and practical contributions from a host of academic disciplines, among them art, theology, and law. The field's most prominent contributors have been social scientists: psychologists, sociologists, political theorists, and educators. One foundational concept in the discipline of peace studies central to this thesis is Johan Galtung's (1969) understanding of peace and violence. Peace theory is closely connected not only with conflict theory, but similarly with development theory. And peace research, defined as research into the circumstances past, present and future of realizing peace. In his research, Galtung defined violence in three ways: "direct violence," meaning physical harm (as in a punch, a gun shot, or war), "structural violence," or systems of injustice that fuel direct violence (for example policies and institutions that consistently repress or discriminate) and "cultural violence," the mores, symbols, and practices that legitimize acts and systems of violence (such as traditions, flags or festivals) (1990, p. 291). Galtung further divides reconstruction into three subcategories: rehabilitation, rebuilding, and restructuration (1998, p. 53-61). programs can provide rehabilitation and healing through psycho-social programs. One example of this comes from Sri Lanka, where cricket, the country's most popular game, is used to rehabilitate hundreds of child victims of the internal conflict through the Cricket for Change program (Cricket for Change, n.d.). Another example of the use of sport to foster peaceful resolution of conflicts comes from Colombia where the Football for Peace Methodology (Metodología Fútbol por la Paz) has been instrumental in creating opportunities for dialogue via sport.

According to Galtung, conflict, violence, and peace should to be understood as dynamic processes that continually inform each other:

- Cultural violence arises from certain attitudes or beliefs, and thus should be addressed through peace making between parties in conflict;

- Structural violence arises from a structural contradiction, and can be addressed through peace building - changing structural imbalances; and

- Direct violence arises from specific behaviors, and can be changed by a modification in behavior - the work of peace keeping.

Galtung's conceptualization of peace and violence has been tested and built upon by theorists and practitioners alike. His terminology is helpful for explaining the various ways in which sport is perceived as working toward peace.

In this context, this research aims to consider the sport as channel seen by many as a more cost-effective approach for dealing with social problems through some programs and operations than correcting the consequences of aggression, crime, violence, and abuse through police, correctional or social services. 


\section{Symbolic Internationalism Theory:-}

Symbolic internationalism is a micro level theory with majority of its focus laying on individual interpretations of beliefs and meanings in our social lives. (Mead, 1934). Symbolic internationalism claims that individuals in their lives come across with many subjective realities, and they need to form their behaviors according to their own interpretations (Mead, 1934). However, that does not mean that this theory undermines the effects of society over individual. Actually to the theory, group membership is one of the major factors of individual clarifications of reality.

According to this theory, Interactions with other individuals have the potential roles to generate views which will, in return, create subjective or group wise realities that will be perceived as objective realities by those individuals (Mead, 1934). However, perception of these newly created realities (subjective) as constants is a mistake at best. Social participants in a social situation are constantly negotiating a shared definition of the situation, taking one another's viewpoints into account, and interpreting each other's behavior prior to implementing an action, (Vilar, 2001). symbolic interactionism points to interpretation of actions as the root of where meaning is derived (Blumer, 1969) . More specifically, symbolic interactionism posits that meaning arises in the process of interaction between people. Meaning grows out of the ways in which people act toward the person with regard to the thing. Actions define the thing for the person. Meanings are social products, that is creations that are formed in and through the way people interact (Blumer, 1969). Beside that this theory focus on the interactions that are subject to change, transformation, and reinterpretation in the event of coming to contact with members of other groups or simply other individuals. (Sutherland \& Cressey, 1978).

From this theory, sport can strengthen interaction between communities, peoples, groups and societies and hence plays an essential part in preserving open networks of communication in open or inactive circumstances of clashes. In conflict situations, sport can support building a beneficial passage for people affected which is directed towards peaceful reduction of aggressions and tensions.

\section{Scholarly Research Overview}

Recently there are many studies discussed the claim that "sports saves the world." (Black, 2010; Coalter, 2010; Darnell, 2010; Guest, 2005; Riedel,2009), these studies promoting the noble power of sport, additionally providing examples of sport's role in instigating discrimination, separation, and violence. Hoglund, K. and R. Sundberg (2008) analyzed the case of South Africa and its experiences in the use of sports in promotion of social solidity as part of overcoming civil conflict especially in the apartheid era. The author discusses several processes of linking sport to reconciliation such as the 
utilization of symbols and symbolic acts of reconciliation like handshakes and national symbols displayed on flags and sporting uniforms.

Tom Woodhouse (2009) highlights the importance of innovation and creativity in peace building and proposes the use of cultural tools, including sports, as a way to energizing the field of peace studies and conflict transformation.

Furthermore, social club studies are regarded as a socialization tool since they not only help students to take an active role in various social groups when they are directed with good consultant, but also help them to develop good relationships with others (Karsl1, 2006). The concept of socialization is generally defined as one's ability to be in contact with other individuals by joining a social group. According to Tezcan (1994) however, socialization is expressed as one's 'preparation to society' during children's education process. In this respect, socialization will be the process for teaching them some skills such as social roles and attitudes supporting (Setterns, 2002). On the other hand, Levine and Moreland (1994) indicated that individuals gain a group culture as a result of the socialization process and develop communication and interaction skills by communicating with one another in various matters. Moreover, the development of attitudes, skills, and values in students who participate in social club activities, such as viewing differences with acceptance and respect enabling active participation, and gaining rights, freedom, and responsibility awareness, enables schools to establish a democratic school culture and to bring up democratic citizens (Centerville Elementary School, 2014).

Sport clubs present a structure contributing not only to youth' physical and mental development, but also one that supports youth to develop their academic success as a part of school and teaching program. youth gain selfmanagement skills and are prepared to live in a democratic society by participating in social club activities (Stearns \& Glennie, 2010). On the other hand, Broh (2002) emphasized that youth' social ties are strengthened through participation in extracurricular activities.

In another research conducted by Hall (2011), Moreau et al. (2014) and Spaaij (2014), it was found that young people participating in sport programmers experienced strong feelings of group responsibility, care and camaraderie, enhanced inter-personal confidence, freedom to challenge social habits and boundaries, and enhanced feelings of belonging through embodied and emotional experiences associated with being actively involved in a sporting competition and part of a team environment.

Furthermore, according to the Swiss Agency for Development and Cooperation, Sport programs implemented in the slums of Medellin, Colombia have resulted in a drop in criminal behavior while in Brazil, programs such as 
Segundo Tempo are expected to show children a way out of misery and violence (2005, p. 8).

According to all those studies, The current research translated all these goals and aims from participating in the sports into statements and situations to test them on the youth who are involved and integrated in the these sports at the club.

\section{Key Concepts :- \\ Peace Building}

Peace-building has three mutually reinforcing dimensions: 1) security; 2) governance and political; 3) social, economic and environmental. Peacebuilding can be understood as enhancement to preventive diplomacy, peacemaking processes, conflict resolution and peacekeeping operations. It includes trials in the context of emerging, current or post-conflict situations for the clear purpose of preventing violent conflict and promoting permanent and sustainable peace. Many peace-building activities are similar to development cooperation activities in countries that are not affected by conflict, but the context and purposes are different. A conflict-sensitive approach to what should be done and how it should be done is required. The general ambition of peace building is "to identify and support structures that will tend to strengthen and solidify peace in order to avoid a relapse into conflict." ( United Nations, 1992).

\section{Youth definition}

Youth are those in the transitional period between being dependent during their childhood and being independent when they reach adulthood (United Nations, 2014:1, and World Bank, 2007:8). It could also refer to a person between the ages of leaving compulsory education, and finding their first job. (Section for Youth of the Bureau of Strategic Planning, 2004:4).

In Egypt, the State Ministry of Youth affairs defines youth as the age group between 18 - 35 years old (World Bank, 2007:8).

From this perspective of seeing youth as an important valuable resource in the society as full citizens, there should be all means and ways to empower and build their capacities to get their full potential in contributing in the society (Denstad, 2009:15-16).

In this way "youth at the field work starts at around 12 or 13 years of age, and ends either at the end of, or soon after, the teen years $(19,20$ or 21 years old). In the view of some, it extends further, to 24 years of age.

\section{Sports}

Sports are an important tool to maintain and improve the health of youth and overcome the negative effect of the modern living habits (National 
Youth Commission, 1997:47). Sports are also one of the effective means of personal development. Sports help youth acquire personal discipline, leadership and teamwork skills. As well as being a source of joy, sports promote the values of peace, unity, and understanding among youth (Ministry of Home Affairs, Heritage and Sports, 2002:13).

In formulating the definition of sport, consideration was given to its physical, competitive and institutional characteristics, as well as how sport is shaped by social and cultural influences. The idea of 'what is sport' will always vary over time and will reflect popular culture. Sport activities are constantly evolving, with new sports emerging and others receding and with considerable variation across countries. ( Defining Sport and Physical Activity, a Conceptual Model,2008).

\section{Results and discussion:-}

\section{1-Egyptian Sport Clubs : Zohour Club as a Case Study}

Zohour club is considered not only sport place but also social place which contains many games, social and cultural programs for different ages. the club also includes professional teams and some integrated people into international championships that later on guide the way to pursuing athletics as a career, it is one of the most private club at the country, so if anyone needs to be a member of a sporting club like that one, he must follow the registration tasks and make the full payment in cash or with some installments which considered costly for some people to be a member there. People there Enjoying a day by the pool privately, or simply have a place to hang out and eat in some restaurants there in any time. The Club is located in rich area Nasr city and recently has a new branch at New Cairo.

In this context, Ministry of Youth and Sports is the only governmental organization that is concerned with the issues of any Egyptian club. The real role of this ministry and its mechanism of action have been a controversy for a very long time. Before 2000 it was named as the "Higher Council for Youth and Sports", then it became Ministry of Youth (only), then National Council for Youth, then Ministry state of Youth and finally it was integrated with Ministry state of Sports to become Ministry of Youth and Sports. Egyptian sport organizations have traditionally depended on government funding (e.g. Egyptian Sports Council) with little or no support from private sector (Fekry, Zaki, 2006). In recent years, the difficult economic conditions have led to a decrease in financial support from the government and left many Egyptian sport federations with little choice than to look for alternate sources of funding. Shalaby (2004) examined the funding sources of professional Egyptian Football Clubs and the marketing of their commercial rights. He found that within the sport clubs, the majority of companies $(68 \%)$ preferred to sponsor football events. However, the lack of scientific research and the need for 
market research in sports have prevented Egyptian sport federations from taking advantage of marketing opportunities (Fekry, Zaki, 2006). Hence, a thorough analysis of the current environment (political, economical, social, legal, legislative, technological and cultural changes), and its future effects on sports industry will lay the groundwork for developing a marketing strategy for Egyptian sport federations. The club aims to satisfy the desires of members to practice their favorite sport, but not limited to the exercise of sport activity by the athlete himself but also to watch and enjoy some national sporting events such as football games and Olympics and to attend regional festivals and some social, cultural and educational events.

New participation opportunities account for most of the increases in sport participation among girls and women over the past three decades. Prior to 1970 , girls and women did not play sport for one simple reason: teams and programmers did not exist. In recent times, women have not only taken part in different sports but have also entered the more 'male' contact sports such as rugby, soccer and boxing.

\section{2-Social and cultural programs at the club}

According to the observation and participant observation, it has found that the primary purpose of the club programs is to raise physically and mentally healthy individuals who contribute to the society effectively. Another of program's primary functions is to establish an environment for youth not only to continually develop their different skills as a complete individual physically, psychologically and sociologically, but also to become happy and productive individuals who actively participate in social activities.

The programs and projects are initiated and led by adults, yet the program operations were taken with youth in a shared manner. Some cultural programs like seminar, workshops and lecturers develop the skills of young people such as: leadership, negotiation, self-confidence ,etc. They will witness their opinions and experiences being valued and directly contributing to positive change in their community in general.

However, those activities didn't set an important practical ways for some social issues such as racism, discrimination, inequalities and homophobia that are revealed in sport and society. They focus in some general public speech on some topics like the peace and tolerance without analysis the real problem inside the society or trying to discuss some misleading meaning or thought of some violence phenomenon. So most of participants at these prgrams have same view that the cultural and social program didn't embody the principles, orientation and viewpoints that underlie their feelings, desires, thoughts and actions. 
3- Youth' perception for the definition of Peace building based on participation in sport team:

Table (1)

The Relationship between participation in Club sports and feeling of peace

\begin{tabular}{|c|c|c|c|c|}
\hline $\begin{array}{c}\text { Aspects of } \\
\text { relation }\end{array}$ & D. of freedom & $\begin{array}{c}\text { Value (r) } \\
\text { Calculated }\end{array}$ & $\begin{array}{c}\text { Value (r) } \\
\text { table }\end{array}$ & Indication level \\
\hline $\begin{array}{c}\text { Feeling of } \\
\text { Peace }\end{array}$ & $\mathbf{1 1 8}$ & $\mathbf{0 . 5 9 2}$ & $\mathbf{0 . 2 2 8}$ & Sig. \\
\hline
\end{tabular}

Figure (1)

The relationship between being member at sportive programs and the ability to feel peace towards society

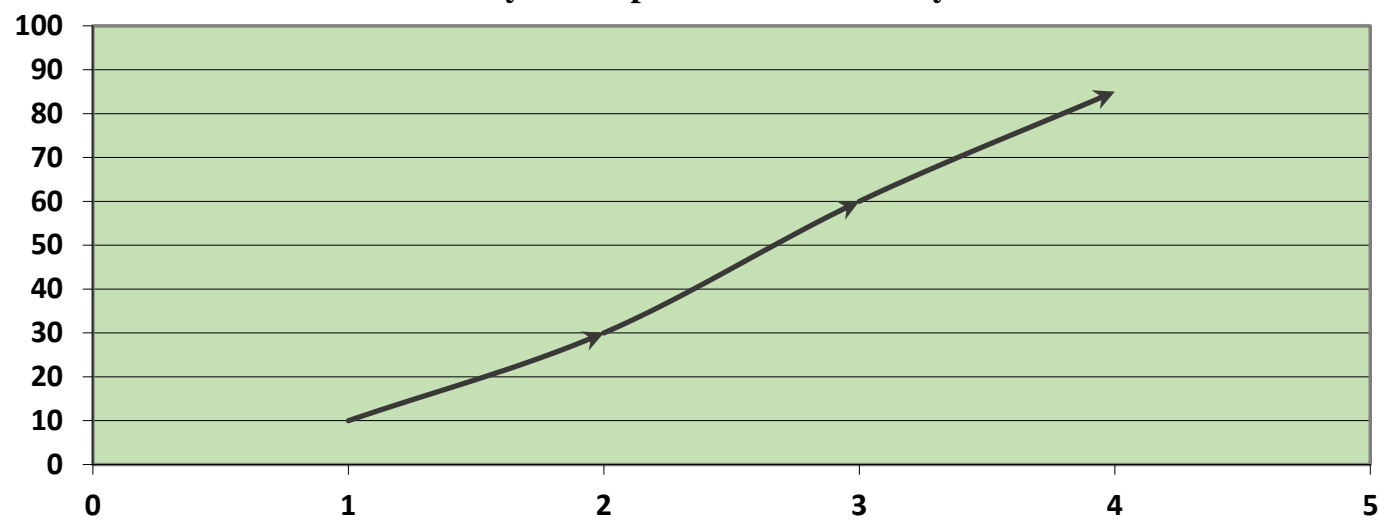

The results revealed according to the table (1) there is spastically relationship between the level of Peace and being member at sportive programs, Using this result, a clear relationship between peace level and participating in some sports program has consistently been noted through the interview and scale as represented in the figure (1), this result was matched and described by previous researcher exactly how sports program affects tolerance and peace, However Youth asserts the increasing need for intercultural programs also to be able to survive in a tolerate society.

Also there is high rate of tolerance towards gender equality and women's empowerment, Also positive attitudes towards women's involvement in the sport. Indeed.

In sum, according to the youth views, participating in sport team program develop skills not only in working with various persons and groups, but also improve their collaboration skills, abilities to apply their knowledge to new situations, and conduct observations, examinations, and analyses. It is concluded from the interview that Young youth using the club for searching for new groups, new ideas and new values to adopt. 


\section{4- Youth' perception for the definition of Peace building based on participation in social and cultural programs:}

Table (2)

\begin{tabular}{|c|c|c|c|c|}
\hline Aspects of relation & $\begin{array}{c}\text { D. of } \\
\text { freedom }\end{array}$ & $\begin{array}{c}\text { Value }(\mathrm{r}) \\
\text { Calculated }\end{array}$ & Value (r) table & Indication level \\
\hline $\begin{array}{c}\text { The Relation between } \\
\text { social and cultural } \\
\text { program and feeling } \\
\text { Peace }\end{array}$ & $\mathbf{1 1 8}$ & $\mathbf{0 . 4 2 1}$ & $\mathbf{0 . 2 2 8}$ & Sig. \\
\hline
\end{tabular}

Figure (2)

The relationship between being member at socio - cultural programs and the ability to feel peace towards society and renounce violence

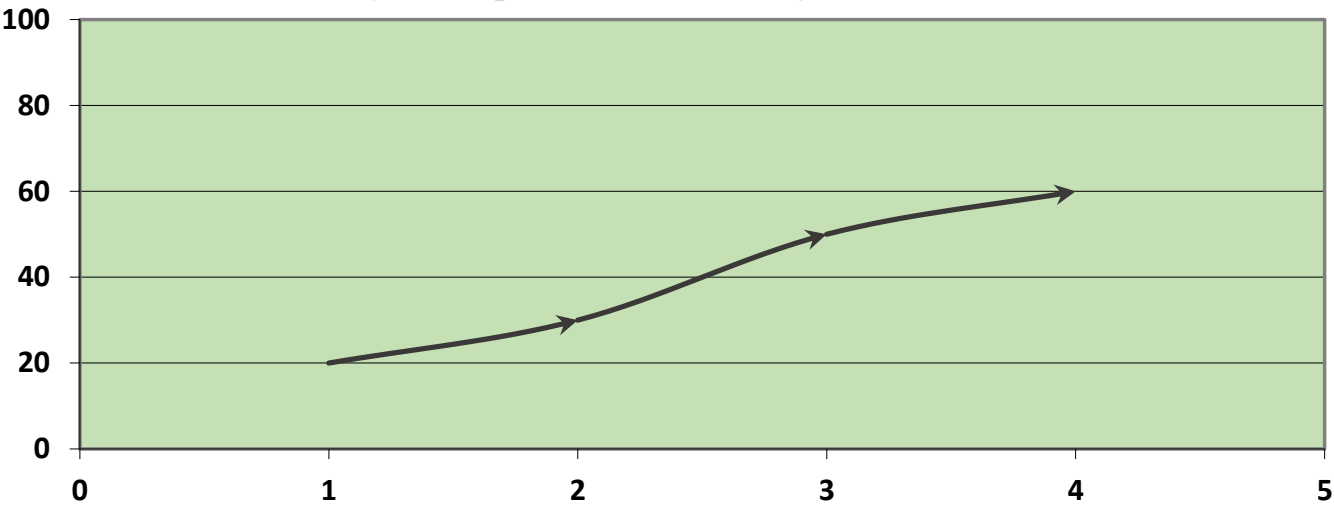

The results revealed according to the table (2) there is spastically relationship between the level of Peace and being member at social and cultural programs, from their views, Joint programmers of culture-based sport for all population groups, as suggested should therefore be established, and the cultural heritage of the various population groups should be included. In doing so, consideration should be given to socio-anthropological factors, (such as age, group membership, language, religion). This percentage of the relationship percentages were associated with a vast statements of their views towards the ability to deal with the other peacefully when they got some cultural sessions and workshop about peace building and human development in general.

Youth are perceived the programs differently, some of them tends to engage at cultural enhancement programs, security programs and business programs , Also they prefer to enrolled into some arts and crafts programs, religious activities and music activities, they mentioned theat they feel peacefully when getting into those classes. Accordingly, their primary focus here is the extent to which involvement in team sports may offer a key site in which to negotiate intercommunity forms of peace building and shared 
vulnerability based on intercultural understandings of embodiment, shared purpose and achievement, and the management of conflict and pressure

\section{5- The aspects of youth interaction inside the club}

Figure (3)

The percentages of interaction aspects

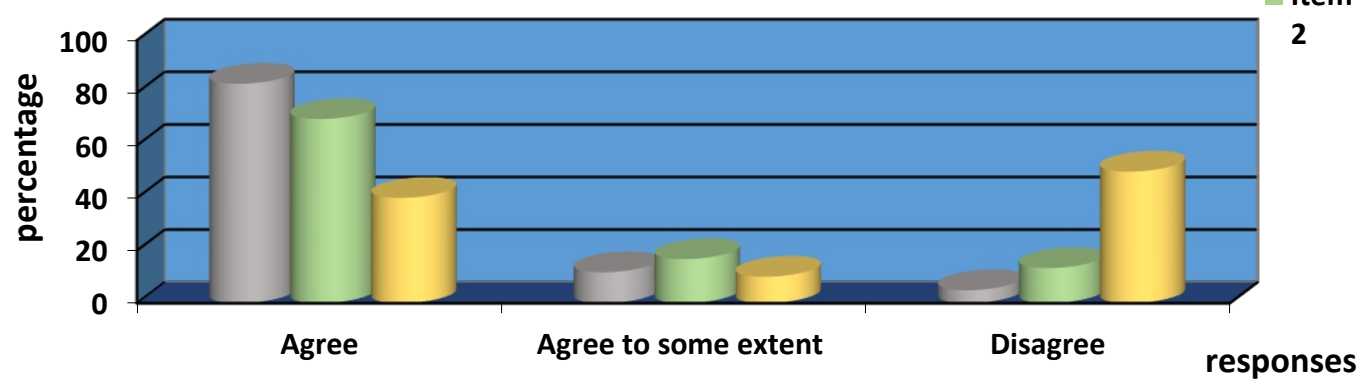

Item 1 following all the international and local sport events at the club Item 2 participating in some sports team

Item 3 Participating in Some cultural and Social programs

Table (4)

Test results $\left(\mathrm{Chi}^{2)}\right.$ to Frequencies the sample responses to verify the first target

\begin{tabular}{|c|c|c|c|c|c|c|c|c|c|c|}
\hline \multirow{3}{*}{$\begin{array}{l}\text { Ite } \\
\text { m } \\
\text { n. }\end{array}$} & \multicolumn{6}{|c|}{ Frequency and percentages of responses } & \multicolumn{4}{|c|}{$\begin{array}{l}\left(\mathrm{Chi}^{2)} \text { To detect the significance of }\right. \\
\text { differences between responses }\end{array}$} \\
\hline & \multicolumn{2}{|c|}{ Agree } & \multicolumn{2}{|c|}{$\begin{array}{c}\text { agree to } \\
\text { some extent }\end{array}$} & \multicolumn{2}{|c|}{ Disagree } & \multirow{2}{*}{$\begin{array}{c}\text { D. of } \\
\text { freedo } \\
\text { m }\end{array}$} & \multirow{2}{*}{$\begin{array}{c}\text { Value } \\
\left(\text { Chi }^{2}\right) \\
\text { Calculat } \\
\text { ed }\end{array}$} & \multirow{2}{*}{$\begin{array}{c}\text { Value } \\
\left(\mathrm{Chi}^{2}\right) \\
\text { table }\end{array}$} & \multirow{2}{*}{$\begin{array}{c}\text { Indication } \\
\text { level } \\
0.01\end{array}$} \\
\hline & $\begin{array}{l}\text { Fre } \\
\text { q. }\end{array}$ & Per. & $\begin{array}{c}\text { Fre } \\
\text { q. }\end{array}$ & Per. & $\begin{array}{l}\text { Fre } \\
\text { q. }\end{array}$ & Per. & & & & \\
\hline $\begin{array}{l}\text { Ite } \\
\text { m } 1\end{array}$ & $\begin{array}{c}10 \\
0\end{array}$ & $\begin{array}{c}83.4 \\
\%\end{array}$ & 14 & $\begin{array}{c}11.7 \\
\%\end{array}$ & 6 & $\begin{array}{l}4.9 \\
\%\end{array}$ & 2 & 22.3 & 9.210 & Sig. \\
\hline $\begin{array}{l}\text { Ite } \\
\text { m2 }\end{array}$ & 84 & $\% 70$ & 20 & $\begin{array}{c}16.7 \\
\%\end{array}$ & 16 & $\begin{array}{c}13.3 \\
\%\end{array}$ & 2 & 17.52 & 9.210 & Sig. \\
\hline $\begin{array}{l}\text { Ite } \\
\text { m3 }\end{array}$ & 48 & $\% 40$ & 12 & $\begin{array}{l}10 \\
\%\end{array}$ & 60 & $\% 50$ & 2 & 13.61 & 9.210 & Sig. \\
\hline
\end{tabular}

According to the Table (4) The majority of youth as represented in the scale \%83.4 prefer to watching and keep following the international and local games at the club more than any place, The result shown also the majority of the sample $\% 70$ is participating in some sports team and willing to be a member and participating in some sports program.

It is shown from the interview especially for the majority of young members, the club is an essential part of their life, and Sport is not only a physical activity but an area where people interact socially and friendly. 
Most of sample confirmed that sport can be a fun activity to be involved in, and positive values learned during games, especially, team cooperation and fair play, Participants reported that sport trainings had increased their confidence both through meeting and addressing issues with peers and coaches as well as by developing their leadership skills, All these views were associated with some researches which declared that youth are willing to participate in some games for some manner development and personality skills (Coalter, 2010).

The experts stated through the interview that team sports force participants to interact which can contribute to building relationships on and outside the field. Moreover, participants may use situations of conflict that naturally arise out of these interactions, to find innovative ways to solve disagreements (for example they refer that they trained the youth to play football matches without referees as a way to encourage participants to negotiate the rules of the game).

On the contrary, It is shown from the scale that few percentage of them $\% 40$ willing to enroll in some cultural and social program at the club as they have more negative attitudes towards the real benefits of participating in cultural and social programs at the club, They don't believe that these programs are the best way to learn them how to interact with the other in appropriate way.

6- youth perception towards the reasons of club participation

Test results $\left(\mathrm{Chi}^{2}\right)$ to Frequencies the sample responses to verify the second target

\begin{tabular}{|c|c|c|c|c|c|c|c|c|c|c|}
\hline \multirow{3}{*}{ Item n. } & \multicolumn{6}{|c|}{ Frequency and percentages of responses } & \multicolumn{4}{|c|}{$\begin{array}{c}\left(\mathrm{Chi}^{2}\right) \text { To detect the } \\
\text { significance of differences } \\
\text { between responses }\end{array}$} \\
\hline & \multicolumn{2}{|c|}{ Agree } & \multicolumn{2}{|c|}{$\begin{array}{l}\text { agree to } \\
\text { some } \\
\text { extent }\end{array}$} & \multicolumn{2}{|c|}{ Disagree } & \multirow{2}{*}{$\begin{array}{c}\text { D. } \\
\text { of } \\
\text { fre } \\
\text { ed } \\
\text { om }\end{array}$} & \multirow{2}{*}{$\begin{array}{c}\text { Valu } \\
\text { e } \\
(\text { Chi } \\
\text { 2) } \\
\text { Calc } \\
\text { ulate } \\
\text { d }\end{array}$} & \multirow[b]{2}{*}{$\begin{array}{c}\text { Value } \\
\left(\mathrm{Chi}^{2}\right) \\
\text { table }\end{array}$} & \multirow{2}{*}{$\begin{array}{c}\text { Indi } \\
\text { catio } \\
n \\
\text { level } \\
0.01\end{array}$} \\
\hline & $\begin{array}{l}\mathbf{F} \\
\mathbf{r} \\
\mathbf{e} \\
\mathbf{q} \\
\text {. }\end{array}$ & Per. & $\begin{array}{l}\text { Fr } \\
\text { eq } \\
\text {. }\end{array}$ & Per. & $\begin{array}{l}\text { Fr } \\
\text { eq. }\end{array}$ & Per. & & & & \\
\hline $\begin{array}{l}\text { It's a chance } \\
\text { to build the } \\
\text { skillset }\end{array}$ & $\begin{array}{l}\mathbf{1} \\
\mathbf{0} \\
\mathbf{0}\end{array}$ & $\begin{array}{c}83.4 \\
\%\end{array}$ & 9 & $\begin{array}{l}7.5 \\
\%\end{array}$ & 11 & $\% 9.1$ & 2 & 21.3 & 9.210 & Sig. \\
\hline $\begin{array}{l}\text { Getting new } \\
\text { friends }\end{array}$ & $\begin{array}{l}9 \\
1\end{array}$ & $\begin{array}{c}75.9 \\
\%\end{array}$ & $\begin{array}{l}1 \\
5\end{array}$ & $\begin{array}{c}12.5 \\
\%\end{array}$ & 14 & $\begin{array}{c}11.6 \\
\%\end{array}$ & 2 & $\begin{array}{c}18.9 \\
1\end{array}$ & 9.210 & Sig. \\
\hline $\begin{array}{l}\text { Listening to } \\
\text { some }\end{array}$ & $\begin{array}{l}7 \\
2\end{array}$ & $\% 60$ & $\begin{array}{l}1 \\
8\end{array}$ & $\begin{array}{l}15 \\
\%\end{array}$ & 30 & $\% 25$ & 2 & $\begin{array}{c}14.8 \\
1\end{array}$ & 9.210 & Sig. \\
\hline
\end{tabular}




\begin{tabular}{|c|c|c|c|c|c|c|c|c|c|c|}
\hline $\begin{array}{l}\text { cultural } \\
\text { lecturers }\end{array}$ & & & & & & & & & & \\
\hline $\begin{array}{c}\text { Intercultural } \\
\text { communicati } \\
\text { on and new } \\
\text { networking } \\
\text { opportunitie } \\
\text { s }\end{array}$ & $\begin{array}{l}7 \\
5\end{array}$ & $\begin{array}{c}62.6 \\
\%\end{array}$ & $\begin{array}{l}2 \\
1\end{array}$ & $\begin{array}{c}17.5 \\
\%\end{array}$ & 24 & $\begin{array}{c}19.9 \\
\%\end{array}$ & 2 & $\begin{array}{c}15.6 \\
4\end{array}$ & 9.210 & Sig. \\
\hline $\begin{array}{c}\text { Society } \\
\text { adoption }\end{array}$ & $\begin{array}{l}8 \\
0\end{array}$ & $\begin{array}{c}66.6 \\
\%\end{array}$ & $\begin{array}{l}1 \\
7\end{array}$ & 14.2 & 23 & $\begin{array}{c}19.2 \\
\%\end{array}$ & 2 & $\begin{array}{c}20.4 \\
1\end{array}$ & 9.210 & Sig. \\
\hline $\begin{array}{l}\text { helps to be } \\
\text { become } \\
\text { more } \\
\text { collaborative }\end{array}$ & $\begin{array}{l}7 \\
5\end{array}$ & $\% 60$ & $\begin{array}{l}2 \\
2\end{array}$ & $\begin{array}{c}20.8 \\
\%\end{array}$ & 23 & $\begin{array}{c}19.2 \\
\%\end{array}$ & 2 & $\begin{array}{c}16.8 \\
9\end{array}$ & 9.210 & Sig. \\
\hline $\begin{array}{l}\text { Social peace } \\
\text { achievement }\end{array}$ & $\begin{array}{l}7 \\
1 \\
\end{array}$ & $\begin{array}{c}59.1 \\
\%\end{array}$ & $\begin{array}{l}2 \\
0\end{array}$ & $\begin{array}{c}16.7 \\
\%\end{array}$ & 29 & $\begin{array}{c}24.2 \\
\%\end{array}$ & 2 & $\begin{array}{c}12.6 \\
4\end{array}$ & 9.210 & Sig. \\
\hline $\begin{array}{l}\text { Feeling Fair } \\
\text { in } \\
\text { completion }\end{array}$ & $\begin{array}{l}6 \\
9\end{array}$ & $\begin{array}{c}57.5 \\
\%\end{array}$ & $\begin{array}{l}2 \\
1\end{array}$ & $\begin{array}{c}17.5 \\
\%\end{array}$ & 30 & $\% 25$ & 2 & $\begin{array}{c}11.3 \\
1\end{array}$ & 9.210 & Sig. \\
\hline $\begin{array}{c}\text { Intellectual } \\
\text { speech } \\
\text { enhancemen } \\
\text { t }\end{array}$ & $\begin{array}{l}8 \\
2\end{array}$ & $\begin{array}{c}68.3 \\
\%\end{array}$ & $\begin{array}{l}1 \\
2\end{array}$ & $\begin{array}{l}10 \\
\%\end{array}$ & 26 & $\begin{array}{c}21.7 \\
\%\end{array}$ & 2 & $\begin{array}{c}14.4 \\
6\end{array}$ & 9.210 & Sig. \\
\hline
\end{tabular}

Table (5)

Test results $\left(\mathrm{Chi}^{2}\right)$ to Frequencies the sample responses to verify the second target

\begin{tabular}{|c|c|c|c|c|c|}
\hline Second target & Freq. & $\begin{array}{c}\text { D. of } \\
\text { freedom }\end{array}$ & $\begin{array}{c}\text { Value }\left(\mathbf{C h i}^{2}\right) \\
\text { Calculated }\end{array}$ & $\begin{array}{c}\text { Value } \\
\left(\mathbf{C h i}^{2}\right) \\
\text { table }\end{array}$ & $\begin{array}{c}\text { Indication } \\
\text { level } \\
\text { 0.01 }\end{array}$ \\
\hline $\begin{array}{c}\text { The reason of } \\
\text { participating in } \\
\text { sports and social } \\
\text { programs }\end{array}$ & 3 & 2 & 15.33 & 9.210 & Sig. \\
\hline
\end{tabular}

The Scale shown that the first reason for youth to participate at sport and social programs is to enhance their skills inside the team which represents $83.4 \%$, they engaged at the team as the better way for knowing some specific roles, develop the ability of competition. It offers also the chance to develop and build skills that they wouldn't get to otherwise. Participation and working with others helps youth to round out your soft skills. One of them stated "It's a great way to build your professional skills including leadership, teamwork, communication and prioritization, also some youth stated that sports offer an opportunity to demonstrate the time management 
Also it was revealed from the scale that one of the most important attributes of sport is its capacity to connect peoples and communities in an extremely effective manner. These communities, when they are inclusive, turn into important sources of social networking fostering community capacity to work cooperatively.

Also the scale shown that getting new friends is considered the main reason for youth to participate at the club, Through the interview one of them stated "you can make a lot of new friends, Clubs have a considerable number of members, so you're bound to hit it off with some of them". Another one stated "They may also invite you to join in other activities outside the club, so you will get to know even more people. So if your social circle has shrunk or you've just relocated, look for a club that interests you".

The results here confirm and match with the definition of Social participants as the theory of symbolic interactionism went through, Youth here admitted that Joining in some programs and making group discussion around some topics corrected their perceptions about the philosophy of competition itself , However they criticize the real benefits of those programs as it came in unorganized ways and couldn't transfer some social and cultural definitions to each one participating in the different games.

Also, around \%60 of the sample stated that Involvement in these groups allows to create collaborative work experiences, such as planning events, creating learning material or performing community service, one of them stated" the club learns how to identify and work toward a shared vision, delegate tasks and responsibilities and work through interpersonal conflict". through the scale $62.2 \%$ responded that they integrated into the club for Intercultural communication and new networking opportunities, one of them stated "Getting involved on campus can increase your peer network, which in turn, increases your exposure and learning".

Several developmental theories point out the importance of adult mentoring for child and adolescent development. Mentoring relationships are important characteristics of clubs and youth programs. However, participation in supervised constructive activities provides adolescents with opportunities to gain social skills from positive interactions with peers. 


\section{7- Youth vision for the club program improvements}

Table (6)

Test results $\left(\mathrm{Chi}^{2}\right)$ to Frequencies the sample responses to verify the second target

\begin{tabular}{|c|c|c|c|c|c|c|c|c|c|c|}
\hline \multirow{3}{*}{ Item $\mathrm{n}$. } & \multicolumn{6}{|c|}{ Frequency and percentages of responses } & \multicolumn{4}{|c|}{$\begin{array}{l}\left(\text { Chi }^{2}\right) \text { To detect the significance of } \\
\text { differences between responses }\end{array}$} \\
\hline & \multicolumn{2}{|c|}{ Agree } & \multicolumn{2}{|c|}{$\begin{array}{l}\text { agree to } \\
\text { some extent }\end{array}$} & \multicolumn{2}{|c|}{ Disagree } & \multirow{2}{*}{$\begin{array}{c}\text { D. } \\
\text { of } \\
\text { fre } \\
\text { ed } \\
\text { o } \\
\text { m }\end{array}$} & \multirow{2}{*}{$\begin{array}{l}\text { Value } \\
\left(\mathbf{C h i}^{2}\right) \\
\text { Calculat } \\
\quad \text { ed }\end{array}$} & \multirow{2}{*}{$\begin{array}{c}\text { Valu } \\
\text { e } \\
\left(\mathbf{C h i}^{2}\right. \\
)^{\prime} \\
\text { table }\end{array}$} & \multirow{2}{*}{$\begin{array}{c}\text { Indicat } \\
\text { on level } \\
0.01\end{array}$} \\
\hline & $\begin{array}{l}\text { Fr } \\
\text { eq. }\end{array}$ & Per. & $\begin{array}{l}\text { Fr } \\
\text { eq. }\end{array}$ & Per. & Freq & Per. & & & & \\
\hline $\begin{array}{c}\text { Security } \\
\text { Control for the } \\
\text { youth } \\
\text { community }\end{array}$ & $\begin{array}{c}11 \\
8\end{array}$ & $\begin{array}{c}98.4 \\
\%\end{array}$ & 1 & $\begin{array}{l}0.8 \\
\%\end{array}$ & 1 & $\begin{array}{l}0.8 \\
\%\end{array}$ & 2 & 29.41 & 9.210 & Sig. \\
\hline $\begin{array}{c}\text { Promoting } \\
\text { Lecturers } \\
\text { about social } \\
\text { peace }\end{array}$ & $\begin{array}{c}11 \\
4\end{array}$ & $\begin{array}{c}95.1 \\
\%\end{array}$ & 6 & $\begin{array}{l}4.9 \\
\%\end{array}$ & $\mathbf{0}$ & $\% 0$ & 2 & 26.52 & 9.210 & Sig. \\
\hline $\begin{array}{l}\text { increase youth, } \\
\text { marketability }\end{array}$ & $\begin{array}{c}11 \\
4\end{array}$ & $\% 95$ & 6 & $\% 5$ & 0 & $\% 0$ & 2 & 32.57 & 9.210 & Sig. \\
\hline $\begin{array}{c}\text { Religious } \\
\text { activities and } \\
\text { cultural } \\
\text { competition }\end{array}$ & $\begin{array}{c}10 \\
5\end{array}$ & $\begin{array}{c}87.5 \\
\%\end{array}$ & 15 & $\begin{array}{l}12 . \\
\% 5\end{array}$ & $\mathbf{0}$ & $\% 0$ & 2 & 27.67 & 9.210 & Sig. \\
\hline $\begin{array}{l}\text { Art and music } \\
\text { activities }\end{array}$ & 99 & $\begin{array}{c}82.4 \\
\%\end{array}$ & 11 & $\begin{array}{l}9.2 \\
\%\end{array}$ & 10 & $\begin{array}{l}8.4 \\
\%\end{array}$ & 2 & 24.48 & 9.210 & Sig. \\
\hline $\begin{array}{l}\text { Discussing the } \\
\text { social issues at } \\
\text { the mosque }\end{array}$ & 29 & $\begin{array}{c}24.2 \\
\%\end{array}$ & 54 & $\begin{array}{l}44 . \\
\% 9\end{array}$ & 37 & $\begin{array}{c}30.9 \\
\%\end{array}$ & 2 & 10.86 & 9.210 & Sig. \\
\hline $\begin{array}{l}\text { Youth violence } \\
\text { prevention }\end{array}$ & $\begin{array}{c}11 \\
5\end{array}$ & $\begin{array}{c}95.9 \\
\%\end{array}$ & 3 & $\begin{array}{l}2.5 \\
\%\end{array}$ & 2 & $\begin{array}{l}1.6 \\
\%\end{array}$ & 2 & 25.79 & 9.210 & Sig. \\
\hline $\begin{array}{l}\text { Cultural and } \\
\text { tourism } \\
\text { activities }\end{array}$ & $\begin{array}{c}11 \\
8\end{array}$ & $\begin{array}{c}98.4 \\
\%\end{array}$ & 2 & $\begin{array}{l}1.6 \\
\%\end{array}$ & $\mathbf{0}$ & $\% 0$ & 2 & 29.88 & 9.210 & Sig. \\
\hline
\end{tabular}

Table (6)

Test results $\left(\mathrm{Chi}^{2)}\right.$ to Frequencies the sample responses to verify the third target

\begin{tabular}{|c|c|c|c|c|c|}
\hline $\begin{array}{c}\text { Third target } \\
\text { Freq. }\end{array}$ & $\begin{array}{c}\text { D. of } \\
\text { freedom }\end{array}$ & $\begin{array}{c}\text { Value }\left(\mathbf{C h i}^{2}\right) \\
\text { Calculated }\end{array}$ & $\begin{array}{c}\text { Value } \\
\left.\text { (Chi }^{2}\right)\end{array}$ & $\begin{array}{c}\text { Indication } \\
\text { table }\end{array}$ & $\begin{array}{c}\text { level } \\
\text {.0.01 }\end{array}$ \\
\hline $\begin{array}{c}\text { Club } \\
\text { improvements } \\
\text { based on youth } \\
\text { vision }\end{array}$ & 3 & 2 & 26.82 & 9.210 & Sig. \\
\hline
\end{tabular}


The scale shown that the majority $\% 95$ responded that they eager to develop their club and to increase youth marketability among them, they stated that Involvement in clubs can be a great way to start garnering impressive skills and hands-on experience that can catch the eye of hiring managers until you're able to build up that cushion of on-the-job professional involvement.

Youth indicated that recently, There has been an increase in private, elite training facilities that are dedicated to producing champion athletes who will be able to compete at the highest levels in youth sport with the other clubs.

There is also increased parental involvement and concern about the participation and success of their young members, and parents are most likely to act in extreme ways as they support the interest of their children to have some hopes or being clever in their sports.

According to the scale, youth built their opinions through their experience in the different teams, they mentioned that the sport in fact, fulfill this function and play this challenging role, depends to a large extent on the specific way in which sport is organized and presented. They mentioned the program of Youth employment and training should be included, which requires a dual emphasis on workforce development and youth development.

From their perspectives, the programs should link with the modernistic business basics, marketing tourism, technology tools and communicate with global or local community leaders. They suggested through the club, youth can engage in a new public dialogue about challenges and opportunities of sport, social responsibility and development. Also they need to have the opportunity to produce creative works for audiences by putting on shows and plays. They need to have more clarification about the racial and socioeconomic barriers that are breached by the work of such organizations is likely to benefit both youth and communities.

Youth admitted that Al- Zohour club provides opportunities for youth to participate in activities, interact with peers in a supervised setting, and form relationships with adults, However they criticize that club because it focus on a specific area, thus allowing members to develop their skills and interests in that area. But they aware that some clubs provide an array of activities from which children and adolescents can choose and expanding the activities which can be useful in their entire life.

This result was confirmed from another study of high school students who shown that about 25 percent of adolescents join music-oriented clubs, such as choir or band, and 20 percent join academic or career-related clubs, such as a science club, a Spanish club, or Future Farmers of America. More children from middle-class families than from lower-class families report participating in school clubs. Participation is also higher in rural or small schools. 
The sample argued that they need extra definitions and applications from the religious, art and cultural program , They indicated that the role of those programs are limited to some general statement advices or lectures, However they expected to receive more impacts such as facilitating and implementing projects and programs that contribute directly to youth development and raise the quality of life, they mentioned Youth violence prevention, examining general violence prevention, lecturer-based violence prevention programs \%95.9, bullying prevention, sexual abuse prevention should be included, In this regard the scale shown that they refused to transfer these activities to be just some religion lessons at the mosque as they emphasis on the way to create some lecturer about moral, values and shared some activities which can acquired easily through participating inside it.

They suggested through the interview some extra programs which may develop their character such as the development of cultural and health awareness program, Participation in the provision of a decent economic situation program, maximizing the use of free times, Enhancing communication and dialog program, Youth social recreation, exploring both the barriers that stand in the way of youth participation in social recreation activities as well as proven strategies for increasing their participation and enhancing the benefits that they derive from these programs, promoting youth leadership (including youth-led initiatives) and facilitating the involvement of youth in community organizing, social activism and civic engagement

They also emphasized that the club administration should make regular invitation to all the members to participate into different activities which are important in several ways. For one, participation in a supervised constructive activity limits the time that is available for less constructive activity, such as television watching, or for getting involved in risky behaviors. For another, activities offered by clubs or youth organizations enable members to learn valuable skills. This result of the youth vision came in the similarity of Galtung theory as he confirmed that sport of peace should focus on reconstruction not only developing the games which divide subcategories: rehabilitation, rebuilding, and restructuration process.

\section{Conclusion and Recommendation}

Peace, stability, and human rights are essential for achieving development not only in Egypt but also in the world at large. Social peace and stability play a significant role in achieving human wellbeing and development. It is for this reason that the sport clubs suggests that peace is one of the essential elements for delivering on the sustainable development goals.

This paper explores various ways clubs practitioners can significantly contribute towards peace-building and development in Egypt. The paper advances the need to include a component of peace and human rights in the 
social and cultural programs. Training, it is assumed, would help prepare adults to effectively engage with the communities in promoting peace and development. This would also unify the concepts of peace with the profession's commitment to promoting social peace and justice.

According to this study, using observations, surveys, and interviews, found that most of youth mentioned that the psychosocial benefits far more often than physical characteristics of the clubs.

One conclusion is that participation in fine arts programs appears to contribute to better academic performance and psychological well-being, even when taking prior academic performance and psychological functioning into account. Another conclusion is that young people can derive developmental benefits from participating in well-run organizations.

\section{References:}

1. Amanda S. Munroe, B.A., PEACE EDUCATION THROUGH SPORT: CRITICAL PEDAGOGY FOR CONFLICT LITERACY, Washington, D.C. April 30, 2012

2. Bergesen, A. J, \& Lizardo, O. (2004). International Terrorism and the World-System. Sociological Theory. 22, 38-52.

3. Black, D. R. (2010). The ambiguities of development: implications for 'development through sport' Sport and Society, 13, 1 121-129.

4. Coakley, J. (2011). Youth sports: What counts as "positive development"? Journal of Sport and Social Is-sues, 35(3), 306-324.

5. Coalter, F. (2013). "There is loads of relationships here": Developing a programmer theory for sport-for-change programs. International Review for the Sociology of Sport, 48(5), 594-612.

6. Coalter, F. (2010). The politics of sport-for-development: Limited focus programs and broad gauge problems? International Review for the Sociology of Sport, 45, 295-314.

7. Esposito, J. L., \& Dalia M. (2007). Who speaks for Islam? What a billion Muslims really think? New York: Gallup Press.

8. Fekri, Y. ,Zaki, I.(2006). The reality of sports marketing in Egypt in light of some of the Contemporary global trends. Theoretical and practical journal, faculty of sports educations for men , university of Alexandria, vol. (60).

9. GIULIANOTTI, RICHARD (2011). "Sport, peacemaking and conflict resolution: a contextual analysis and modeling of the sport, development and peace sector". Ethnic and Racial Studies. Vol. 34, iss. 2, pp. 207-228.

10. Gottier, A. (2011, September 21). New Dance Organizations. The International Platform onSport and Development. Retrieved From (Swiss Agency for Development and Cooperation, 2005). 
11. Hall, N. (2011). "Give it everything you got": Resilience for young males through sport. International Journal of Men's Health, 10(1), 65-81.

12. Hoffman, B. (1999) "The Mind of the Terrorist: Perspectives from Social Psychology.” Psychiatric Annals, Vol. 29, no. 6, pp. 337-340

13. Kimivaki (2003, pp. 4-5) suggests religious tolerance (TOLERANCE) as another influential variable to people's.

14. Lederach, J. (2003). "Conflict Transformation”. Beyond $\begin{array}{lll}\text { Intractability. } & \text { Retrieved } & 3.23 .12\end{array}$ http://www.beyondintractability.org/bi-essay/transformation

15. Mead, G. H. (1934). Mind, self, and society. Chicago: University of Chicago Press.

16. Moreau, N., Chanteau, O., Benoît, M., Dumas, M.-P., LaurinLamothe, A., Parlavecchio, L., \& Lester, C. (2014). Sports activities in a psychosocial perspec-tive: Preliminary analysis of adolescent participation in sports challenges. International Review for the So-ciology of Sport, 49(1), 85-101.

17. Ross, J.I. (1996) "A Model of the Psychological Causes of Oppositional Political Terrorism," Peace and Conflict: Journal of Peace Psychology, Vol. 2, no. 2, pp.129-141

18. Sandford, R. A., Duncombe, R., \& Armour, K. M. (2008). The role of physical activity/sport in tackling youth disaffection and antisocial behaviour. Educational Review, 60(4), 419-435.

19. Shalaby, S. (2004). A Study of Marketing Management of Sport Sponsorship Rights in first class Clubs in Egypt. Faculty of sports education for men conference, university of Alexandria.

20. SUDGEN, John; HAASNER, Adrian (2009). Sport interventions in divided societies. [Online document]. [Retrieved 9 September 2010].

21. Sutherland, E. H. \& Cressey, D. R., (1978). Criminology. Philadelphia: J.B. Lippincott Company.

22. SWISS AGENCY FOR DEVELOPMENT AND COOPERATION (2005). Sport for development and peace. Berne.

23. Terrorism Research Center. Under the subject" Definitions", [Online] Available http://www.terrorism.com/terrorism/def.shtml

24. Thamer Ibrahim Aljahmani, the concept of terrorism in international law, the first edition, Houran Publishing House, Damascus, 1998.

25. Turk, A. T., (2004). Sociology of Terrorism. Annual Review of Sociology. 30, 271-286 
26. United Nations, An Agenda for Peace: Preventive Diplomacy, Peacemaking and Peace-keeping, UN. Doc. A/47/277 and S/24/111, 17 June 1992, para. 46.

27. Whitehead, J. C. (1987). Terrorism: The Challenge and the Response, Journal of Palestine Studies. 6, 215-221.

28. WOODHOUSE, TOM (2009). "Building a global peace culture". Conflict and culture roundtable, cultural initiatives in peace building. Tokyo: Joint Research Institute for International Peace and Culture.

29. Zaki, I., Fekri, Y.(2006). Examine of self-financing in Egyptian Olympic sports Federations. Theoretical and practical journal, faculty of sports educations for men, university of Alexandria, vol. (59). 